\title{
A MENT AL HEALTH PREVALENCE SURVEY IN TWO DEVELOPING TOWNS OF WESTERN REGION
}

\author{
Upadhyaya K D*, Pol K*
}

\section{ABSTRACT}

A prevalence survey was done to find out the conspicuous psychiatric morbidity (CPM) in two rapidly developing towns of western region by using Self - Rating Questionnaire (SRQ). Out of 894 people interviewed 773 were selected for analysis. The CPM point prevalence rate of $35.4 \%$ was found. The high prevalence of CPM was most likely due to less stable social structure in the towns in transition.

\section{INTRODUCTION}

The Western Regional Community Mental Health Programme (WRCMHP) is a Pokhara based programme from the Institute of Medicine (IOM). The aims of the programme are: i.) train primary health care workers to identify common psychiatric disorders and epilepsies and start treatment or refer them to centres where treatment services are available ii) increase awareness in the community about the need of proper treatment and follow-up of mental disorders. In this background WRCMHP wanted to have epidemiological data on mental health problems, in two rapidly growing towns of the Western region namely Walling bazaar of Syangja district and Kusma bazaar of Parbat district.

\section{METHODOLOGY}

The survey was done with a Self Rating Questionnaire (SRQ), a 24 item inventory which allows determination of the prevalence of "conspicuous psychiatric morbidity (CPM)". A simple 'yes' or 'no' can answer these questions. The aim of the first 20 questions is to uncover 'neurotic' or rather 'nonpsychotic' symptoms; the remaining four questions for psychotic symptoms. If the number of 'yes' answers to the first 20 questions exceeds a pre determined number, and/or at least one 'yes' answer is given on the 'psychotic' questions, it is likely that the respondent is suffering from some form of mental disorder or has a CPM. A previous study showed the prevalence of CPM in primary care clinics ranged from $10.6 \%$ to $17.7 \%$ (mean $13.9 \%$ ) in five of the seven centres studied. ${ }^{1}$

The SRQ was produced from existing western questionnaires such as the Symptoms and Signs Inventory (SSI), ${ }^{2}$ General Health Questionnaire(GHQ) ${ }^{3}$ and the Present State Examination (PSE). ${ }^{4}$ According to those who developed the SRQ, this instrument enables respondents from different cultures the opportunity 'to report the presence or absence of clearly defined symptoms'. Kortmann, in his own validity study on SRQ, states that 'everywhere in the world people with mental problems give substantially more 'yes' answers to the SRQ than people who do function well psychologically. ${ }^{5}$

Our choice of the SRQ was based on the fact that it already has been used in Nepal. ${ }^{6}$ The survey did not use the SRQ questionnaire used by Wright, since the language was found difficult. The SRQ was translated into simple Nepali. For this, the procedure of translating, independently back translating and then discussing the points of disagreement was followed. In addition to the core instrument, the questionnaire contained questions to acquire socio-demographic data, substance use data, prevalence of epilepsy (questions no 25) and the help seeking behaviour questions. The questionnaire was pre-tested

* Western Regional Hospital, Pokhara, Nepal.

Address for correspondence : Dr. Kapil Dev Upadhyaya

Western Regional Hospital

Pokhara, Nepal.

Email: drkapilnpl@hotmail.com 
in medical and psychiatric OPD of Western Regional Hospital (WRH). Five experienced interviewers were recruited; they were given one day training in administering the questionnaire. These interviewers administered the questionnaire. Self reporting was not feasible as the majority of the people surveyed were illiterate villagers.

\section{SAMPLING METHOD}

Two towns were chosen, Kusma of Parbat district and Walling of Syangja district of the Western Region. Both these towns are rapidly growing and can be said' the towns in transition'. Both these towns have nine wards. In all wards of these towns four areas were selected by random sampling. All houses in these selected areas were visited and two persons (when possible one male and one female member) over 15 years of age were interviewed. The clients were explained about the purpose of interview and permission was taken before administering the instrument. None of the clients refused for the interview, rather more people showed interest to participate.
The interview was held during the whole day from morning to the early evening to include both people working inside and outside the house.

\section{RESULTS}

Sample profile: The study was conducted in late 1998. A total of 894 people were interviewed, of which $52 \%$ of the interviewees were women. Of these, 773 were selected for analysis 366 males and 407 females.

Cut off score: In the study of Wright et al, more than 10 'yes' answers on non-psychotic list meant that some one had CPM and having 10 or less 'yes' answers meant non-CPM.? Same cut off score of more than 10 'yes' was taken in this study.

\section{Prevalence of CPM}

In the study population 274 (35.4\%) reported enough symptoms and score to classify them as having CPM and 499 (64.5\%) as non-CPM.

Table I : Distribution per age group

\begin{tabular}{c|c|c|ccc}
\hline Age group in years & $\mathbf{1 5}-\mathbf{1 9}$ & $\mathbf{2 0}-\mathbf{2 9}$ & $\mathbf{3 0}-\mathbf{3 9}$ & $\mathbf{4 0}-\mathbf{4 9}$ & $\mathbf{5 0}-\mathbf{~ 5 9}$ \\
\hline Number & 62 & 195 & 193 & 163 & 160 \\
\hline
\end{tabular}

Table II : Marital status per sex

\begin{tabular}{l|l|r}
\hline \multirow{3}{*}{ Women } & Married and only wife & $57.4 \%$ \\
\cline { 2 - 3 } & Married and first wife & $18.5 \%$ \\
\cline { 2 - 3 } & Married and being second wife & $7.6 \%$ \\
\cline { 2 - 3 } & Widowed & $7.1 \%$ \\
\cline { 2 - 3 } & Unmarried & $9.4 \%$ \\
\hline \multirow{3}{*}{ Men } & Married, only one wife & $70.0 \%$ \\
& Married having more wives & $8.6 \%$ \\
& Unmarried & $19.7 \%$ \\
& Widowed & $0.8 \%$ \\
& Divorced & $0.8 \%$ \\
\hline
\end{tabular}

Table III : Distribution per ethnic group

\begin{tabular}{cc|c|cc}
\hline Brahmin/Chhetries & Gurungs & Magars & Newars & Occupational (group)/Castes \\
\hline 303 & 160 & 95 & 102 & 113 \\
\hline
\end{tabular}

Table IV : Education

\begin{tabular}{c|cc|c|c}
\hline Illiterate & Nonformal education & School dropouts & SLC pass & Higher education \\
\hline $292(37.8 \%)$ & $280(36.2 \%)$ & $53(6.8 \%)$ & $112(14.2 \%)$ & $36(4.6 \%)$
\end{tabular}

Table IV shows that more than $74 \%$ did not receive any formal education, only $20 \%$ did have SLC and $3.8 \%$ did get higher education.

Table V : Occupation

\begin{tabular}{c|c|c|cc|c|ccc|c}
\hline Farmer & Housewife & $\begin{array}{c}\text { Govt. } \\
\text { Job }\end{array}$ & Business & Teacher & Student & $\begin{array}{c}\text { Health } \\
\text { Professional }\end{array}$ & $\begin{array}{c}\text { Labor } \\
\text { work }\end{array}$ & $\begin{array}{c}\text { Truck } \\
\text { driver }\end{array}$ & Unemployed \\
358 & 21 & 39 & 175 & 9 & 47 & 2 & 90 & 2 & 30
\end{tabular}


Table VI : Distribution of CPM in men and women

\begin{tabular}{c|c|c}
\hline Sex & CPM & Non-CPM \\
\hline Male & $103(28 \%)$ & $263(71.8 \%)$ \\
\hline Female & $171(42 \%)$ & $236(58 \%)$ \\
\hline
\end{tabular}

Table VII : Ethnicity and CPM

\begin{tabular}{l|c|c}
\hline \multicolumn{1}{c|}{ Ethnicity } & Total No. & No. of CPM \& their \% \\
\hline Brahmin/Chhetries & No. 303 & $43(14.1 \%)$ \\
\hline Gurungs & No. 160 & $27(16.8 \%)$ \\
\hline Magar & No. 95 & $27(26.4 \%)$ \\
\hline Newar & No. 102 & $31(32.6 \%)$ \\
\hline Occupational groups & No. 113 & $54(47.8 \%)$ \\
\hline
\end{tabular}

\section{DISCUSSION}

The CPM point prevalence rate of $35.4 \%$ is surprisingly high. The underlying assumption of the null hypothesis of the study was that in towns of the transition, the social structure is less stable and therefore more mental health problems. Mumford found in studies in Pakistan similar high results with a comparable instrument. ${ }^{8,9}$

Other very apparent outcomes of the study are the high occurrence of CPM in occupational castes (47.8\%) and in women $(36.6 \%)$. Also the proportion of illiterate people having CPM is high (47.6\%). The literacy rate in Nepal is lowest in occupational groups and women. Poverty, unemployment, illiteracy, social status, expectation of social support and hope of better health care may have relationship with high CPM. Further research needs to be done to explore possible relationship.

We were not able to find exact explanation for the high prevalence of CPM in the two surveyed towns; however the instrument is valid for detecting CPM. We would like to accept the hypothesis that social structure is less stable in towns in transition towards modernization and CPM scores are high in such communities.

\section{ACKNOWLEDGEMENT}

We would like to thank interviewers Krishna Hari Sapkota, Jaganibas Bhandari, Sharada Dhakal, Shiva Chapagain, Dilli Prasad Sharma and Ramchandra Poudel for their excellent data collection. Special thanks to all respondents.

\section{REFERENCES}

1. Hardi ng, T.W/ et al (980) ' nent al di sor ders i n pri nary care: a st udy of thei $r$ frequency and di agnosi s i nf our devel opi ng countri es; Psychol Ned D, 231 ñ 241

2. Foul ds, GA; Hope, K(1968) Manual of the sympt ons si gn i nvent ory SS, London Press.

3. Gol dberg, D.P.; Cooper , B; East nood, MR, Kedward; H.B. Shephard, M970)" "Ast andar d psychi atri c i nt ervi ewf or use i ncomnoni ty surveys"Bri ti shj ournal of Preventi ve Nedi ci ne, 24, $17-24$.

4. Wing, J .K., Cooper, J.E., Sart or i ous, N (1974) The neasurenent and cl assi $\mathrm{i} i$ cati on of of psychi atri c symptons. Canbri dge; Canbri dge Uni versi ty press.

5. Kor tmann, F. (1987)' Probl ens i n communi cat i on i n transcul tural psychi atry, Act a psychi atr. Scand; $7,563-50$.

6. Wi ght, C ( 1991 Commoni ty Mental Heal th Servi ce Fi ve years on, and what has been I earnt? J . Nep. Med. Assoc; 29, D2130 .

7. Wi ght, G; Nepal, MK; Bruce-J ones, WDA (1990) Ment al Heal th Pati ents i n Pri nar y Heal th Care Servi ces i n Nepal .J . I nst. Med; D, 65 ñ 74.

8. Munfiord DB; Nazi r, ; J i l ani , F.M et al (1996) Stress and psychi atri c di sorders i ntheH ndukush: Acomoni ty survey of a nount ai nvi I I agei nchi tral ,Paki stan. Br.J. Psychi atry, 68, 299 ก̃ 307.

9. Munfiord, DB; Saeed, K; Ahned, I; Lati f, S and Mubbasher, MH (997) Stress and psychi atri c di sor der i n rural Punj ab. A commeni ty survey. Br.J. Psychi atry, 170, 1473 - 1776.

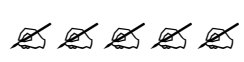

